ISSN 0258-7122 (Print), 2408-8293 (Online)

Bangladesh J. Agril. Res. 44(2): 281-290, June 2019

\title{
EFFECT OF FOLIAR SPRAY OF GA 3 AND NAA ON SEX EXPRESSION AND YIELD OF BITTER GOURD
}

\author{
R. KHATOON ${ }^{1}$, M. MONIRUZZAMAN ${ }^{1}$ AND M. MONIRUZZAMAN ${ }^{3}$
}

\begin{abstract}
A field experiment was conducted at the Plant Physiology field of Horticulture Research Center, BARI, Gazipur during two consecutive years of kharif 2014 and 2015 to assess the effect of $\mathrm{GA}_{3}$ and NAA on sex expression, yield and yield components of bitter gourd (Momordica charantia L.) var. BARI Karola-1. Eeleven treatments comprising five concentrations each of gibberellic acid (50, 100, 150, 200 and 300 ppm) and naphthalene acidic acid (50, 100, 150, 200 and $300 \mathrm{ppm}$ ) along with distilled water considered as control were evaluated in randomized complete block design with three replications. Gibberellic acid $\left(\mathrm{GA}_{3}\right)$ and Naphthalene acidic acid (NAA) were sprayed at 4 leaf stage; second spray was done at 35-38 DAS and third spray done at flowering stage. All the treatments improved the flowering and yield characters over control. Foliar spray of NAA @ $150 \mathrm{ppm}$ and $200 \mathrm{ppm}$ was found better in terms of sex expression, yield and yield attributes of bitter gourd as compared to control and other treatments. Spray of NAA @ 150 ppm gave the lowest number of male flowers and the highest number of female flowers thereby produced the lowest sex ratio (male:female). Number of fruits/plant, individual fruit weight and fruit yield/plant were also found maximum from NAA $150 \mathrm{ppm}$. Maximum fruit yield was recorded with the application of NAA @ 150 ppm. Spraying of NAA @ 150 ppm gave the maximum gross return and net return with the highest BCR of 3.17.
\end{abstract}

Keywords: Gibberellic acid, Naphthalene acidic acid, sex expression, fruit yield, bitter gourd.

\section{Introduction}

Bitter gourd (Momordica charantia L.) locally known as "Karola", belonging to the family Cucurbitaceae is one of the most important popular vegetables in Bangladesh. The fruit is a rich source of vitamin $\mathrm{C}$, iron, phosphorous and carbohydrates (Behera, 2004). This vegetable is a different nature's bountiful gifts to mankind, which does not only have fabulous digestional properties, but also it is a storehouse of remedies for many common ailment such as diabetes, rheumatism and gout (Mia et al., 2014). The fruit accumulates bitterness with time due to build up of three pentacyclic triterpenes momordicin, momordicinin and momordicilin, and then loses the bitterness during ripening (Cantwell et al., 1996).

\footnotetext{
${ }^{1 \& 3}$ Scientific Officer, Horticulture Research Centre, Plant Physiology Section, Bangladesh Agriculture Research Institute (BARI), Gazipur, ${ }^{2}$ Principal Scientific Officer, Horticulture Research Centre, Plant Physiology Section, BARI, Gazipur, Bangladesh.
} 
Bitter gourd is a monoecious plant naturally, inducing greater number of male flowers than the female flowers and this flowering behavior is not advantageous and economical, because it results in lower fruit set and yield (Mangave et al., 2016). To have the higher yield, the male and female flower ratio needs to be decreased and synchronized. Maleness and femaleness can usually be altered by environmental variables such as temperature, photoperiod and nutrition or by the application of growth regulators (Krishnamurthy, 1981). It is seen that proper and judicious use of plant growth regulators (PGRs) is one of the ways to increase the yield of bitter gourd by inducing female flowers and reducing male flowers. Gibberellic acid $\left(\mathrm{GA}_{3}\right)$ and naphthalene acetic acid (NAA) are two important growth regulators that are used to modify the growth, yield and yield contributing characters of cucurbitaceous crops (Rafeekar et al., 2002; Iqbal et al., 2013; Chovatia et al., 2010; Dalai et al., 2015: Singh et al., 2015). GA 3 plays a key role in promoting male sex expression and are antagonistic to that of ethylene and abscisic acid (Rudich, 1983: Zhang et al., 2017). Exogenous application of $\mathrm{GA}_{3}$ promotes female flowers as well as fruit setting and development of bitter gourd crop (Banerjee and Basu, 1992). External application of NAA in bitter gourd also increased the yield of the crop (Melisa and Nina, 2005; Biradar et al., 2010). The information regarding increasing fruit yield of bitter gourd by using plant growth regulators is scanty in Bangladesh. Since, very little information is available on the effect of growth regulators on sex expression and yield of bitter gourd in Bangladesh, the present investigation was undertaken to find out the suitable plant growth regulators $\left(\mathrm{GA}_{3}\right.$ and NAA) with appropriate doses for increasing the fruit yield potential of bitter gourd.

\section{Materials and Methods}

The experiment was conducted at the Plant Physiology field of Horticulture Research Center, Bangladesh Agricultural Research Institute (BARI), Gazipur during kharif season of consecutive two years of 2014 and 2015. The bitter gourd variety used in this study was BARI Karola-1. The experiment consisted of eleven treatments viz., control (distilled water), 5 concentrations of $\mathrm{GA}_{3}(50,100$, 150, 200 and $300 \mathrm{ppm}$ ) and five concentrations of NAA (50, 100, 150, 200 and $300 \mathrm{ppm}$ ). Randomized complete block design with three replications was used for the experiment. At first sandy loam soil and well decomposed cowdung were thoroughly mixed in 1:1 ratio and then plastic pots were filled with this mixture. Seeds were placed in plastic pots on 01 February 2014 and 05 February 2015. Before sowing, seeds were soaked in tap water for 24 hours. There were 33 unit plots measuring $4.0 \mathrm{~m} \times 2.4 \mathrm{~m}\left(9.6 \mathrm{~m}^{2}\right)$ and each plot contained four pits. After final land preparation, pits were prepared by spade and each pit was $30 \times 30 \times 30$ $\mathrm{cm}$ in size. The land was fertilized with 120-40-80-30-2-4 kg/ha of N-P-K-S-B$\mathrm{Zn}+5.0$ t/ha cowdung (Shamima et al., 2013). The source of N, P, K, S, B and $\mathrm{Zn}$ were urea, TSP, MoP, gypsum, boric acid (17\% B) and zinc sulphate. The total amount of cowdung, $\mathrm{P}, \mathrm{S}, \mathrm{B}, \mathrm{Zn}$ and one-third of each $\mathrm{N}$ and $\mathrm{K}$ were applied in pits before transplanting. The rest of urea of $\mathrm{N}$ and $\mathrm{K}$ were applied in 
four equal installments at 20,35, 55 and 75 days after transplanting (DAT). Fifteen days old seedlings were transplanted in the field on 20 February, 2014 whereas 16 days old seedlings were transplanted on 26 February 2015. Plants were spaced at $2.0 \times 1.2 \mathrm{~m} . \mathrm{GA}_{3}$ and NAA were first sprayed at 4 leaf stage (22 and 24 days old seedlings in the 1 st and $2^{\text {nd }}$ year, respectively); second spray was done at 20 and 22 days after transplanting in $1^{\text {st }}$ and $2^{\text {nd }}$ years, respectively (35 and 38 days after sowing) and third spray was done at first flowering stage. Control plants were sprayed with distilled water. Branches of bamboo (kanchi) were used for the support of the plants. Plants were allowed to be grown individually and not be allowed to intermingle with other plants grown beside. Weeding and irrigation were done as required. The sequential pickings of fruits started from the $2^{\text {nd }}$ week of April and continued to 14 and 20 July of 2014 and 2015 , respectively. When $1^{\text {st }}$ flower was seen, the number of male and female flowers was tagged and thereafter was counted. The cost of cultivation and gross returns from the crop were calculated on the basis of local market prices of inputs and farm gate price of bitter gourd. Net returns were worked out by subtracting the total cost of cultivation under each treatment from the gross return of respective treatment. Benefit cost ratio (BCR) was worked out by dividing the gross return with total cost of production. Data were recorded on days to first female flowering, number of male flowers/plant, number of female flowers/plant, number of fruits/plant, individual fruit weight, number of seeds/fruit and yield/plot. Plot yield was then converted to per hectare yield. Recorded data were statistically analyzed by MSTAT-C and mean separation was done by Duncan Multiple Range Test (DMRT) at 1\% and 5\% level of probability. Benefit-cost Ratio (BCR) analysis was also done.

\section{Results and Discussion}

\section{Effect of $\mathrm{GA}_{3}$ and NAA on sex expression of bitter gourd}

Gibberellic acid $\left(\mathrm{GA}_{3}\right)$ and Naphthalene acetic acid (NAA) had significant effect on days to $1^{\text {st }}$ female flowering, number of male flowers and number of female flowers/plant (Table 1). NAA $150 \mathrm{ppm}$ took the minimum time (33.00 days in 2014 and 32.80 days in 2015 for the appearance of first female flower followed by NAA 200 ppm (34.00 and 33.60 days in 2014 and 2015, respectively) and maximum time were required by $\mathrm{GA}_{3} 300$ ppm (42.00 days in 2014 and 42.82 days in 2015). The mean data also showed that NAA $150 \mathrm{ppm}$ required minimum days for first female flowering closely followed by NAA 200 ppm. Maximum number of male flowers/plant was recorded in $\mathrm{GA}_{3} 300 \mathrm{ppm}$ (301.15 in 2014 and 310.18 in 2015) followed by $\mathrm{GA}_{3} 100 \mathrm{ppm}$ (289.09) in 2014 and $\mathrm{GA}_{3} 200 \mathrm{ppm}$ (253.50/plant) in 2015 and it was minimum in NAA $150 \mathrm{ppm}$ (121.79 and 129.80 in 2014 and 2015, respectively). Similar result was also observed in mean data in terms of number of male flowers/plant. The control gave 191.94 and 221.34 male flowers/plant in 2014 and 2015, respectively. It was observed that all concentrations of $\mathrm{GA}_{3}(50-300 \mathrm{ppm})$ produced higher number of male flowers than control in both the years and all NAA concentrations (50-300 ppm) gave lower number of male flowers than control. 


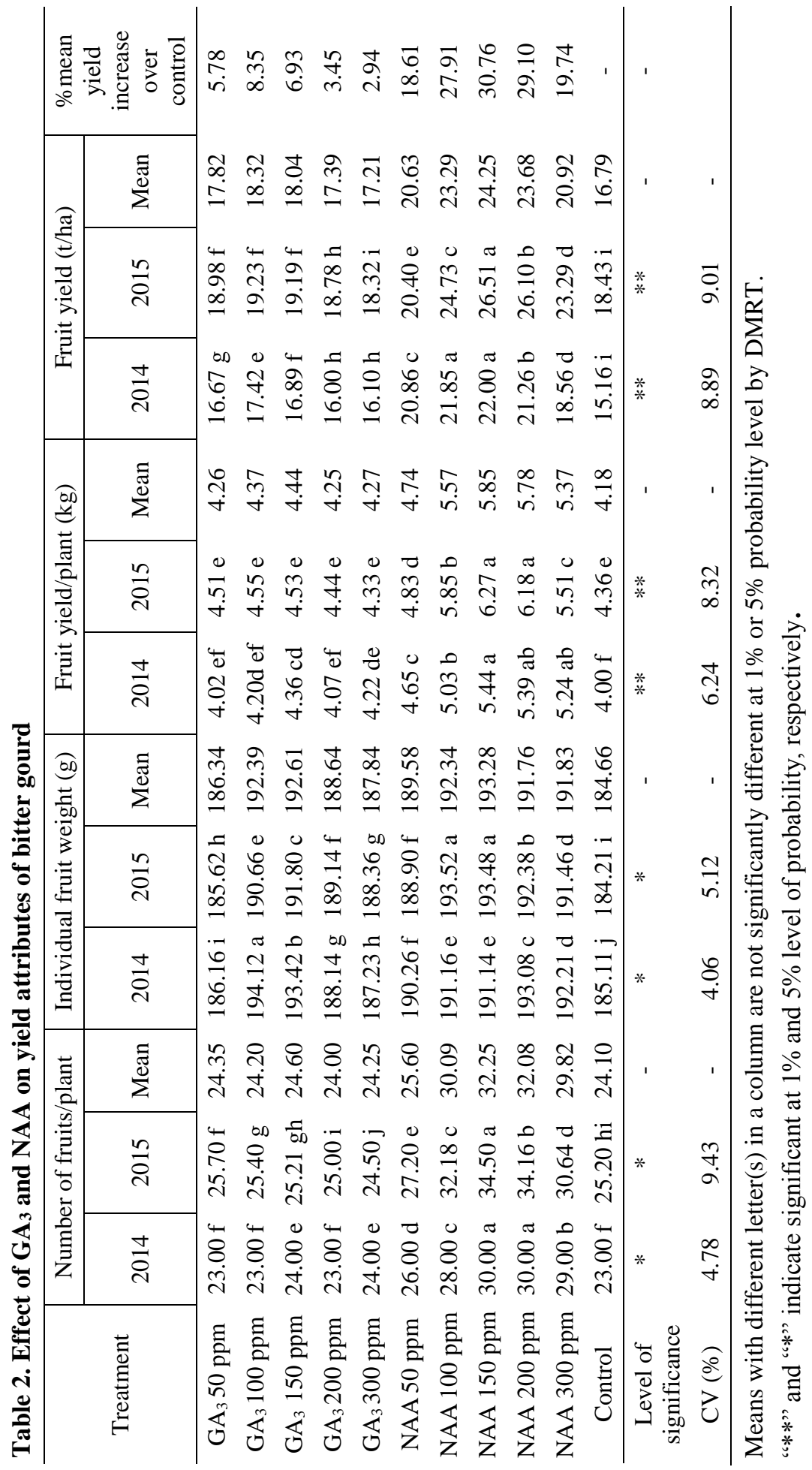


The highest number of female flowers/plant was obtained from NAA $100 \mathrm{ppm}$ (46.00 in 2014, 55.16 in 2015 and mean value was 50.58 in mean data) followed by NAA 150 ppm $(44.00$ in $2014,54.62$ in 2015 with mean 49.31) and it was minimum in control (27.00 and 35.70 in 2014 and 2015, respectively and 31.35 in mean). In both the years, $\mathrm{GA}_{3} 50 \mathrm{ppm}$ and $100 \mathrm{ppm}$ gave the lowest female flowers which were also less than the values obtained from any concentration of NAA except control. It indicates that NAA 100 ppm was capable of producing maximum female flowers/plant in both the years. Growth regulators increased the female flowers in the present investigation, which might be due to increase in the mobilization of auxin substances in plants and also in reduction of sugar thereby bringing a change in membrane permeability. This corroborates the result of Dixit et al. (2001). Choudhury and Singh (1970), and Bisaria (1974) reported that NAA $100 \mathrm{ppm}$ decreased the male flowers and increased the female flowers in cucumber. Mangave et al. (2016) obtained minimum number of male flowers and maximum number of female flowers/plant with the application of $75 \mathrm{ppm}$ NAA. Pandey and Singh (1976) found that spraying of NAA at 100 and 150 ppm, and $\mathrm{GA}_{3}$ at $10 \mathrm{ppm}$ increased the female flowers and decreased the male flowers per plant in sponge gourd. In the present experiment, all concentrations of $\mathrm{GA}_{3}$ increased male flowers per plant than control. This might be happened due to use of high concentrations of $\mathrm{GA}_{3}$ beyond $10 \mathrm{ppm}(50-300 \mathrm{ppm})$. The lowest sex ratio (male:female) was recorded in NAA 150 ppm (2.77 in 2014, 2.38 in 2015 and 2.57 in mean data) followed by NAA 200 ppm ( 3.68 in 2014 and 3.09 in 2015) and NAA 100 ppm (3.88 in 2014 and 3.34 in 2015). GA $@ 50$ ppm and all concentrations of NAA decreased the sex ratio compared to control. Application of NAA at optimum concentration could be attributed to the suppression of male flowers and promoted more number of female flowers. Sex ratio mainly depends on the viable and compatible features of male and female organs. The narrower sex ratio by the spraying of NAA is possibly due to the fact that this substance is reported to increase functional male organs and compatibility besides the embryo abortion in plants (Gill et al., 2012).

\section{Effect of $\mathrm{GA}_{3}$ and NAA on yield attributes and yield of bitter gourd}

The maximum number of fruits/plant was obtained from both NAA $150 \mathrm{ppm}$ and NAA $200 \mathrm{ppm}$ (30.00) in 2014 but in 2015, NAA $150 \mathrm{ppm}$ performed the best (34.50) closely followed by NAA $200 \mathrm{ppm}$ (34.16) and the mean showed that maximum fruits/plant in NAA $150 \mathrm{ppm}$ closely followed by NAA $200 \mathrm{ppm}$ (Table 2). All concentrations of NAA produced higher number of fruits/plant compared to all concentrations of $\mathrm{GA}_{3}$ and control. In 2014, maximum individual fruit weight was obtained from $\mathrm{GA}_{3} 100 \mathrm{ppm}(194.12 \mathrm{~g})$ followed by $\mathrm{GA}_{3} 150$ ppm (193.42 g) and NAA $200 \mathrm{ppm}(193.08 \mathrm{~g})$ but in 2015, individual fruit weight was maximum in NAA 100 ppm (193.52 g) closely followed by NAA 
$150 \mathrm{ppm}(193.48 \mathrm{~g})$ and NAA $200 \mathrm{ppm}(192.38 \mathrm{~g})$. Mean maximum individual fruit weight of 2014 and 2015 were recorded from NAA 150 (193.28 g) ppm followed by $\mathrm{GA}_{3} 150 \mathrm{ppm}(192.61 \mathrm{~g}), \mathrm{GA}_{3} 100 \mathrm{ppm}(192.39 \mathrm{~g})$ and NAA 100 $(192.34 \mathrm{~g})$. Minimum individual fruit weight was recorded from control in both the years and also in mean value. The results revealed that growth regulators treated plants gave higher individual fruit weight compared to control.

Maximum fruit yield/plant was found in NAA $150 \mathrm{ppm}$ in both the years $(5.44$ $\mathrm{kg} /$ plant in 2014 and $6.27 \mathrm{~kg} /$ plant in 2015 as well as in mean value $(5.85$ $\mathrm{kg} /$ plant).The lowest yield/plant was obtained from control in 2014 and 2015 and from their mean data.

NAA $150 \mathrm{ppm}$ gave the highest yield (22 t/ha in 2014, $26.51 \mathrm{t} / \mathrm{ha}$ in 2015 with mean value of $24.25 \mathrm{t} / \mathrm{ha}$ ) that was closely followed by NAA $100 \mathrm{ppm}$ ( $21.85 \mathrm{t} / \mathrm{ha})$ in 2014 but in 2015 , NAA $150 \mathrm{ppm}$ gave statistically higher fruit yield than NAA $200 \mathrm{ppm}(26.10 \mathrm{t} / \mathrm{ha})$. The control gave the lowest yield in $2014(15.16 \mathrm{t} / \mathrm{ha})$ but in $2015, \mathrm{GA}_{3} 300 \mathrm{ppm}$ showed a lowest yield (18.32 $\mathrm{t} / \mathrm{ha}$ ). NAA treated plants produced yield in the range of $18.56-22.00 \mathrm{t} / \mathrm{ha}$ in 2014 and 20.40-26.51 t/ha in 2015. Mean yield increase over control revealed that plants of bitter gourd treated with 100 and 150 ppm NAA gave $27.91 \%$ and $30.76 \%$ higher yield, respectively. Iqbal et al. (2013) reported that NAA 100 and $150 \mathrm{ppm}$ produced better yield and yield related traits in bitter gourd among each of three $\mathrm{GA}_{3}(25,50 \& 75 \mathrm{ppm})$ and NAA concentrations (50, 100 and $150 \mathrm{ppm}$ ). The increase in fruit yield with NAA may be due to the effect of auxins to cause physiological modifications in the plants mainly on sex ratio, increased fruit set, fruit weight and higher photosynthetic activity, synthesis and translocation of metabolites from source to sink points (Hilli et al., 2010).

\section{Economics}

The present study (Table 3) revealed that maximum gross return (Tk $7,27,500.00$ ) was found maximum from NAA $150 \mathrm{ppm}$ followed by NAA 200 ppm (Tk 7,10,400.00) and $100 \mathrm{ppm}(\mathrm{Tk} 6,98,700.00)$ and the minimum gross return was recorded from control (Tk 5,34,600.00). Net return showed marked difference among the treatments and followed the same trend of gross return. Net return was the highest (Tk Tk 4,97,923.00) in NAA $150 \mathrm{ppm}$ followed by NAA $200 \mathrm{ppm}(\mathrm{Tk} 4,79,283.00)$ and NAA $100 \mathrm{ppm}(\mathrm{Tk} 4,70,663.00)$ while the lowest (Tk 2,78,743.00) in control. The maximum benefit cost ratio (BCR) (3.17) was obtained from NAA $150 \mathrm{ppm}$ followed by NAA $200 \mathrm{ppm}$ (3.07) and NAA 100 ppm (3.06) while the minimum (2.24) from control. The cost and return analysis revealed that spraying of NAA @ 150 ppm was superior to NAA 100 and 200 ppm in terms of net income and BCR. 
Table 3. Benefit cost analysis of bitter gourd production by using plant growth regulators

\begin{tabular}{c|c|c|c|c|c|c}
\hline Treatments & $\begin{array}{c}\text { Mean } \\
\text { fruit } \\
\text { yield } \\
\text { (t/ha) }\end{array}$ & $\begin{array}{c}\text { Gross } \\
\text { return } \\
\text { ('000 Tk) }\end{array}$ & $\begin{array}{c}\text { Cost of } \\
\text { treatment } \\
\text { ('000 Tk) }\end{array}$ & $\begin{array}{c}\text { Total cost of } \\
\text { cultivation } \\
\text { ('000 Tk) }\end{array}$ & $\begin{array}{c}\text { Net return } \\
\text { ('000 Tk) }\end{array}$ & $\begin{array}{c}\text { Benefit- } \\
\text { cost ratio } \\
\text { (BCR) }\end{array}$ \\
\hline $\mathrm{GA}_{3} 50 \mathrm{ppm}$ & 17.82 & 534.60 & 5.46 & 230.42 & 304.18 & 2.32 \\
$\mathrm{GA}_{3} 100 \mathrm{ppm}$ & 18.32 & 549.60 & 11.51 & 236.47 & 313.13 & 2.33 \\
$\mathrm{GA}_{3} 150 \mathrm{ppm}$ & 18.04 & 541.20 & 16.78 & 241.74 & 299.46 & 2.24 \\
$\mathrm{GA}_{3} 200 \mathrm{ppm}$ & 17.39 & 521.70 & 21.84 & 246.80 & 274.90 & 2.11 \\
$\mathrm{GA}_{3} 300 \mathrm{ppm}$ & 17.21 & 516.30 & 32.76 & 257.72 & 258.58 & 2.00 \\
$\mathrm{NAA}^{\prime} 50 \mathrm{ppm}$ & 20.63 & 618.90 & 1.54 & 226.50 & 617.36 & 2.73 \\
NAA 100 ppm & 23.29 & 698.70 & 3.08 & 228.04 & 470.66 & 3.06 \\
NAA 150 ppm & 24.25 & 727.50 & 4.62 & 229.58 & 497.92 & 3.17 \\
NAA 200 ppm & 23.68 & 710.40 & 6.16 & 231.12 & 479.28 & 3.07 \\
NAA 300 ppm & 20.92 & 627.60 & 9.24 & 234.197 & 393.403 & 2.68 \\
Control (water & 16.79 & 503.70 & 0.00 & 224.96 & 278.743 & 2.24 \\
spray) & & & & & & \\
\hline
\end{tabular}

Basic cost of cultivation: 224.957 thousand Tk.

Cost of PGRs:

1. Gibberellic acid $\left(\mathrm{GA}_{3}\right)$ : Tk 500.00/g

2. Naphthalelene Acetic Acid (NAA): Tk 2200.00/100 g

Market selling price of fruits: Tk 30.00/kg (Tk 30000.00/ton)

\section{Conclusion}

Based on the findings of the present study, it can be concluded that NAA treated plants performed better in respect of sex expression, yield and yield attributes of bitter gourd as compared to $\mathrm{GA}_{3}$. Application of NAA @ 150 and 200 ppm proved better and produced lower sex ratio by increasing the female flowers over control by suppressing male flowers, and gave maximum number of fruits per plant and finally yield per hectare with the maximum BCR of 3.17 and 3.07, respectively. Therefore, it can be recommended for the farmers to spray NAA @ 150-200 ppm at four leaf stage, 35 days after sowing (DAS) and at first flowering stage for obtaining higher yield of bitter gourd.

\section{References}

Banarjee, S and P. S. Basu. 1992. Hormonal regulation of flowering and fruit development: Effect of gibberellic acid and ethrel on fruit setting and development in Momordica charantia. Biologia Plantarum. 34: 63-70.

Behera, T. K. 2004. Heterosis in bittergourd. J. New Seeds. 6 (2/3): 217-222. 
Biradar, G., C. M. Nawalagatti, M. B. Dodaamani and M. B. Cheti. 2010. Effect of plant growth regulator on morphological parameters and yield in bitter gourd. Int. J. Agril. Sci. 6 (2):504-507.

Bisaria. A. L. 1974. Sex expression and fruit development in cucumber as affected by gibberellins. Indian J. Hort. 16: 233-235.

Cantwell, M., X. Nie, R. J. Jhong and M. Yamagachu. 1996. Asian vegetables: selected fruits and leafy types. Progress in new crops. Ed: Janick, J., V. A. Arington, ASHS press. pp. 488-495.

Choudhury, B. and N. Singh. 1970. Chemical sex modification and its effect on fruit of cucumber (Cucumis sativus L) at three locations. Indian J. Hort. 27 (3/4): 180-183.

Chovatia, R. S., T. R. Ahlawat, Y. A. Kavathia, L. L. jivani and D. C. Kaila. 2010. Effect of plant growth regulators on vegetative growth, flowering and yield of bitter gourd cv. Priya. Indian J. Hiort. 67 (special issue): 254-258.

Dalai, S., M. K. Singh, K. V. Singh, M. Kumar, S. Malik and V. Kumar. 2015. Effect of foliar application of $\mathrm{GA}_{3}$ and NAA on growth, flowering, yield and yield attributes of cucumber (Cucumis sativus L.) Annals of Horticulture. 8 (2): 181-194.

Dixit, A., N. Rai and V. Kumer. 2001. Effect of plant growth regulators on growth, earliness and sex ratio in water melon under Chhatgarh region. Indian J. Agril. Res. 35: 173-176.

Gill, J., W. S. Dhilon, P. P. S. Gill and N. Singh. 2012. Fruit set and quality improvement studies on bitter gourd. Indian J. Hort. 69 (1):39-44.

Hilli, J. s., B. S. Vyakarnahal, D. P. Biradar and R. Hunje. 2010. Effect of growth regulators and stage of spray on growth, fruit set and seed yield of ridge gourd ( Luffa acutangula L. Roxb.). Karnataka J. Agric. Sci. 23 (2): 239-242.

Iqbal, Q., A. Nawaz, T. Ahmed, O. B. A. Hafiz and M. Abbas, 2013. Efficacy of plant growth regulators on sex expression, earliness and yield components in bitter gourd. Pakistan J. life. Social Sci. 11 (3): 23-31.

Krishnamurthy, H. N. 1981. Plant Growth Substances. Tata McGraw-Hill Pub. Com. Ltd. New Delhi. pp. 138-126.

Mangave, B. D., S. S. Dekhane and D. J. Patel. 2016. Effect of plant growth regulators on growth and sex expression of bitter gourd. Int. J. Dev. Res. 6 (4): 7310-7312.

Melissa, F. T. and M. C. Nina. 2005. Effects of naphthalene acetic acid (NAA) and gibberellic acid $\left(\mathrm{GA}_{3}\right)$ on fruit morphology, parthenocarpy, alkaloid and chlorophyll content in bitter gourd (Momordica charantia L. 'Makiling'). Phillipines Agric. Sci. 88: $35-39$.

Mia, M. A. B., M. S. Islam and J. H. Shamsuddin. 2014. Altered sex expression by plant growth regulators: an overview in medicinal vegetable bitter gourd (Momordica charantia L). J. Medicinal Plant Res. 8 (8): 361-367.

Pandey, R. P. and K. Singh. 1976. Effect of plant growth regulators on sex expression, fruit set and yield of sponge gourd (Luffa cylindrical Poem.). Hortic. Abstract. 499 (11): 733 .

Rafeekar, M., S. A. Nair. P. N. Sorte. G. P. Hatwal and P. M. Chandan 2002. Effect of growth regulator on growth and yield of summer cucumber. J. Soils \& Crops. 12: 108-110. 
Rudich J, 1983. Conference on the biology and chemistry of cucumber. Cornell Univercity, Ithace. New York. August 1980.

Shamima, N, R. Ahmed and M. N. Uddin. 2013. Requirment of N, P, K and S for yield maximization of bitter gourd (Momordica charantia). Bangladesh J. Agril. Res. 38 (2): 355-361.

Singh, M. S., S. Dalai, K.V. Singh, M. Kumar and S. K. Lodhi.2015. Sex modification and yield of cucumber (Cucumis sativus L.) as influenced by different levels of auxins and gibberellins. HortFlora Research Spectrum. 4 (4): 329-332.

Zhang, Y., G. Zhao, Y. Li, N. Mo, J. Jhang and Y. Liang. 2017. Transcriptomic analysis implies that GA regulates sex expression via ethylene-dependent and ethyleneindependent pathways in cucumber (Cucumis sativus L.). Front. Plant Sci. https://doi.org/10.3389/fpls.2017.00010. 